\title{
Supplier relationship management - anathema for the South African public procurement sector
}

\author{
Authors: \\ Micheline J. Naude ${ }^{1}$ \\ Intaher M. Ambe ${ }^{2}$ \\ René Kling ${ }^{3}$

\begin{abstract}
Affiliations:
${ }^{1}$ Department of

Management, Information

Technology and Governance,

University of KwaZulu-Natal,

South Africa

${ }^{2}$ Department of Business Management, University of South Africa, South Africa

${ }^{3}$ Supply Chain Management Education, Australia
\end{abstract}

Correspondence to:

Micheline Naude

Email:

naudem@ukzn.ac.za

Postal address:

Room 26, Commerce

Block, Private Bag X01,

Pietermaritzburg,

South Africa

Dates:

Received: 12 Mar. 2013

Accepted: 23 May 2013

Published: 09 July 2013

How to cite this article:

Naude, M.J., Ambe, I.M. \&

Kling, R., 2013, 'Supplier

relationship management

- anathema for the South

African public procurement sector', Journal of

Transport and Supply Chain Management 7(1), Art. \#93, 8 pages. http://dx.doi.org/ 10.4102/jtscm.v7i1.93

\section{Copyright:}

C 2013. The Authors. Licensee: AOSIS

OpenJournals. This work is licensed under the Creative Commons

Attribution License.

Read online:
The public sector is recognised as being one of the most important customer groups for many suppliers and service providers because of the volume of public expenditure. Supplier relationship management (SRM) is a necessary tool on which businesses in the public and private sectors rely. However, in the South African public sector, despite the intention to boost service delivery through efficient and effective supplier-management processes, the development of sound supplier relationships is a challenge. The purpose of this article is to provide insight into supplier-relationship challenges and to suggest a framework for implementing SRM in the South African public sector. The research presented is based on a survey using both descriptive and exploratory research. Data were gathered through semi-structured interviews with 15 participants at eight institutions in KwaZulu-Natal. Purposive sampling techniques were used. The findings reveal that the main supplier-related challenges that handicap procurement practices in the province are a lack of experience, a lack of affirmable suppliers, threats and bribes, a lack of integrity, an inability to meet delivery deadlines and quality issues. The findings further reveal that supplier relationships in the public sector are of a transactional nature. A five-stage framework is therefore recommended for implementing SRM in the South African public sector and in order to assist government procurement officials to reap the benefits of SRM whilst supporting the requirements of public-sector procurement.

\section{Introduction}

The public sector is one of the most important customer groups for many suppliers and service providers. This is due to the size of the sector and the volume of public expenditure (Hugo \& Badenhorst-Weiss 2011:287). Relationships with customers have always been considered to be important in business management. In the past, relationships with suppliers were regarded as insignificant in the overall performance of organisations. Buyers played suppliers off against one another and frequently switched suppliers. Relationships between buyers and suppliers were cordial, but often adversarial. As indicated in Burt, Dobler and Starling (2003:79) '... a gain for one resulted in a loss for the other, which is often called a win-lose outcome.' This adversarial model was not ideal and was transformed in the early 1990s when buyers started to see the advantages of developing relationships with supplier firms and realised that joining forces with suppliers could lead to competitive market benefits (Monczka et al. 2010:111).

Maintaining positive relationships with suppliers is increasingly being recognised as a critical factor in sustaining a competitive advantage (Stevenson 2009:525). Most businesses view their suppliers as partners; in other words, they seek a stable relationship with comparatively few suppliers that are able to provide high-quality supplies, sustain delivery schedules and remain flexible in relation to changes in specifications and delivery schedules. Various academic texts and journal articles discuss this topic at length and explain how the process of supplier relationship management (SRM) contributes to the success of contractual relationships between buyers and suppliers. However, the public sector has an inherent problem with SRM, as it often sees a negative correlation between building relationships with suppliers and maintaining ethics. This is based on a perception that in order for public procurement officials to form relationships with suppliers, a compromise must be made in relation to their ethics. However, the importance of sound supplier relationships is vital and relationships with suppliers should be viewed as a key strategic activity in the public procurement sector.

In the South African public sector, procurement is a regulated process defined and controlled by numerous laws, rules and regulations, judicial and administrative decisions, policies and procedures (National Treasury 2005). A framework for supply chain management (SCM) governs the way in which procurement is conducted in the public sector and is informed by the Public Finance Management Act, the Preferential Procurement Policy Framework Act 5 of 2000, the Municipal Finance Management Act 56 of 2003 and the Broad-Based Black Economic Empowerment Act 
53 of 2003 (National Treasury 2005; Hugo \& BadenhorstWeiss 2011:287-289). This framework is applicable to all government departments, constitutional institutions and public institutions (Van der Waldt 2007:204). The objective of the framework is to provide value-added goods and services to government customers and it defines supplier relationships with government departments (National Treasury 2005). However, despite the SCM processes that were intended to boost service delivery, many departments in the public sector are still not efficient and effective in implementing these processes. Furthermore, the development of sound supplier relationships is a challenge.

The purpose of this article is (1) to explore supplierrelationship challenges in the South African public sector and (2) to suggest a framework for implementing SRM in the South African public sector. The article begins by reviewing the relevant literature (best practices of SRM, public procurement, procurement in the South African public sector), after which the research design, the discussion of the results and the conclusions are presented.

\section{Literature review}

This section of the article presents an overview of the importance of relationships in the supply chain as an overview of SRM; it provides insight into procurement reforms in South Africa and the legislative framework for public procurement.

\section{Building relationships}

Every business - whether in the public or private sector - is dependent on materials and services supplied by other businesses. As no business is self-sufficient, it can be concluded that sound relationships in the supply chain are vital. When the Harvard Business Review organised a team of leading academics in the discipline of SCM, people and relationships were identified as the major themes for discussion (Beth et al. 2006:65).

According to Monczka et al. (2010:109), most buyers and sellers recognise the need for teamwork between buyers and suppliers as the best way to reduce costs and ensure quality, delivery, time and other measures of performance. The relationship is two-sided, as both parties have the power to shape their nature and future direction. Mutual commitment and balanced power are key features: commitment enables both parties to keep the relationship working over time and balance ensures mutual benefits. This teamwork is often described as SRM.

Burt, Petcavage and Pinkerton (2010:65) acknowledge that buyer-supplier relationships have evolved from being transactional in nature, to being collaborative and alliancebased. However, according to Fawcett, Ellram and Ogden (2007:347), and Swink et al. (2011:294-295), the key is 'an appropriate' relationship that is in accordance with strategic sourcing principles. Some suppliers of less significant standard materials and services receive only limited attention with an arms-length relationship. However, since the emergence of SCM two decades ago, the focus has shifted to long-term engagement and relationships with suppliers of critical and bottleneck materials or services (Wu \& Weng 2010:392; Gullett et al. 2010:330; Ganesan, Brown, Mariadoss \& Ho 2010:361).

Business owners and executives are beginning to realise that strategic supplier alliances, if successful, can result in better market penetration, access to new technology and knowledge, and higher returns on investment than those competitors who do not have such alliances (Wisner, Tan \& Leong 2009:120). However, there is an imbalance of power in the South African public sector. Public entities enjoy a high level of dominance, which may tip the scales in their favour in relationships and when conducting negotiations with suppliers. However, they have to purchase goods and services from the private sector as cost-effectively as possible within the accepted standards of quality of appropriate suppliers.

\section{Why supplier relationship management?}

SRM aims to overcome the traditional adversarial relationship between buyers and suppliers. It is through communication and the sharing of information and ideas that better outcomes are provided for both parties. According to Bailey, Farmer, Jessop and Jones (2005:12), mutual supplier-buyer relationships provide benefits in terms of sharing and exchanging information, with the emphasis on building a 'satisfactory outcome together' in a range of areas.

According to Saunders (1997:255), the outcome of an adversarial relationship is perceived in terms of a 'win-lose' result, whereas the outcome of a partnership relationship is perceived to result in a 'win-win' situation - where both sides win at the same time through the implementation of a problem-solving approach. Burt et al. (2010:68) and Mangan, Lalwani, Butcher and Javadpour (2012:36) agreed that the main distinction between these two relationships is the existence of institutional trust. The authors summarised the following characteristics:

- a recognition of mutual interdependence between the buyer and supplier

- a high level of trust between the organisations

- a high level frequency of both formal and informal communications

- co-operative attitudes

- mutual benefits

- shared risks

- problem-solving, 'win-win' negotiating styles with an emphasis on managing total costs

- long-term business arrangements

- open sharing of information by multifunctional teams

- vendor certification and defect-prevention approaches

- adhering to predetermined payment conditions.

There certainly appears to be a greater focus today on developing long-term relationships that provide mutual advantages when the market place is less certain. However, SRM presents a dilemma to public procurement officials as the SCM policy restricts anyone in public-sector procurement 
from building relationships with their suppliers. Does SRM therefore have a place in public-sector procurement?

\section{South African public-sector supply chain management}

Public procurement has at its core a requirement for transparency and a high standard of ethics with the emphasis on treating all suppliers equally. No one supplier can receive more information than another prior to or during the bidding process (Public Service Commission 2008:45). Procurement in government is a regulated, open process defined and controlled by numerous laws, rules and regulations, judicial and administrative decisions, policies and procedures (Dobler \& Burt 2000:747). Van Weele (2010:106-109) observed that procurement policies in the public sector are informed and constrained by specific circumstances, for example the necessity for public accountability, the fact that public entities are not subject to the rules of the free market and the necessity for specific financial management procedures in government.

In South Africa, public procurement refers to activities related to the purchasing of goods and services that the public sector requires from the private sector (Pauw et al. 2002:227). The main objective of public procurement is to purchase goods and services at the lowest possible cost from appropriate suppliers, whilst maintaining the accepted standards of quality. Purchases by the public sector represent a substantial amount of public resources spend and are a substantial source of income to the private sector (Moeti et al. 2007:122). In view of this, the public sector has identified the need to leverage the substantial amount of public resources spend by making procurement a tool to achieve socioeconomic benefits. As a result, procurement departments have been created in terms of section 38(1[a][iii]) of the Public Finance Management Act 1 of 1999 (Pauw et al. 2002:229). The Public Finance Management Act 1 of 1999 provided for the establishment of SCM systems that have been applied across the public sector. Clearly, government wanted to apply 'best practice' methods of SCM whilst achieving the socioeconomic benefits.

The concept of procurement has evolved rapidly during the last decade. Concepts and approaches such as supply management, strategic sourcing and SCM now exist. Not only are public procurement officials faced with these new developments when conducting business with the private sector, but they are also under pressure to embrace these new approaches. Institutions in the public sector are expected to manage their finances efficiently, particularly in procurement, which is evident from the Public Finance Management Act, preferential procurement regulations and the SCM framework.

Supply chain management is defined in the Municipal Finance Management Act as follows:

Supply Chain Management involves the management of working capital that is invested in goods, stores and services with the objective of optimising the economic return on such investment. The process begins when the needs are identified during the strategic planning phase of the organisation when service delivery targets are identified, to the point of finally disposing of an asset (MFMA [circular 22] 2006:12).

\section{Legislative requirements of supply chain management}

As indicated in Hugo, Badenhorst-Weiss and Van Biljon (2006:336), section 217(1) of the Constitution requires a procurement system that is 'fair, equitable, transparent, competitive and effective'. The Green Paper on Public Sector Procurement Reform states that 'the Government of South Africa is committed to good governance and the elevation of previously marginalised communities' (Peterson 2005:2). Therefore, government is influenced by the following legislative frameworks that guide the SCM policy (Peterson 2005:3):

- Constitution of the Republic of South Africa (Act 108 of 1996);

- Public Finance Management Act (PFMA) (Act 1 of 1999);

- Local Government: Municipal Finance Management Act (MFMA) (Act 56 of 2003);

- Preferential Procurement Policy Framework Act (PPPFA) (Act 5 of 2000);

- Broad-Based Black Economic Empowerment (BBBEE) Act (Act 53 of 2003).

\section{Public sector supply chain management framework}

As indicated in the previous section, SCM in all government bodies works within a legislative framework (Van der Waldt 2007:204). The framework is based on norms and standards that must create uniformity. These norms and standards include fairness, equity, transparency, competitiveness and cost-effectiveness. Figure 1 illustrates the components of the public sector SCM framework.

A brief explanation of the components of this framework follows.

Demand management: Demand management is the first stage of the SCM process and involves evaluating the needs of the end user through market and commodity analysis. It is also the stage during which the specifications are determined and potential suppliers are identified to ensure that the requests are linked to the budget (Van der Waldt 2007:205; MFMA [circular 22] 2006:12).

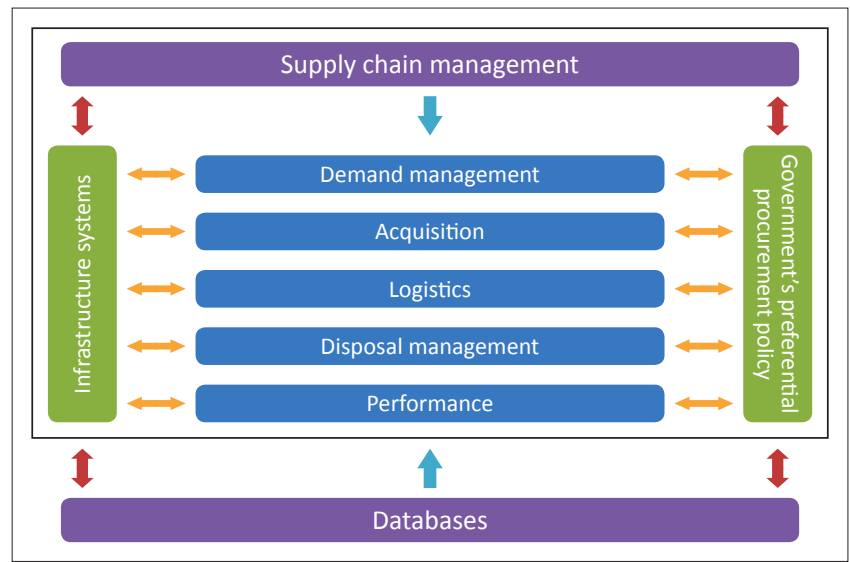

Adapted from these sources: Moeti, K., Khalo, T., Mafunisa, S., Nsingo, S. \& Makonda, T., 2007 Public Finance Fundamentals, 1st edn., p. 129, Juta Academic, South Africa; Van der Waldt, G. 2007, Municipal management: Serving the people, p. 205, Juta \& Co. Ltd, Cape Town; National Treasury, 2004, Supply Chain Management: A guide for accounting officers/authorities, Republic of South Africa, February 2004, p. 11, viewed 05 May 2012, from http://mfma.treasury.gov.za FIGURE 1: Framework of supply chain management. 
Acquisition management: This stage of SCM deals with the process of acquiring goods and services after demand management has been completed. It includes: developing a plan as to how goods and/or services are to be procured; preparing bid documents; advertising these bids; determining the criteria as to how the bids will be assessed; selecting the preferred suppliers or bidders; preparing the contract documentation; and signing the relevant contracts. Activities at this stage are carried out in terms of applicable legislation, namely the Preferential Procurement Policy Framework Act 5 of 2000, the Broad-Based Black Economic Empowerment Act 53 of 2003 and the Municipal Finance Management Act 56 of 2003 (Van der Waldt 2007:205; MFMA [circular 22] 2006:16).

Logistics management: This stage of SCM involves contract and inventory management. The process includes ordering, receiving and coding stock items, distributing stock to customers and managing the warehouse and the transport fleet (Van der Waldt 2007:205; MFMA [circular 22] 2006:46).

Disposal management: During this stage, an assessment is made of stock items that are no longer required or usable and that must be disposed of. The process includes developing a disposal policy, calculating depreciation rates and maintaining a database of all redundant items. Items must be disposed of in terms of the policy determined by the unit within the national and/or provincial department (Van der Waldt 2007:205; MFMA [circular 22] 2006:48).

Performance management: The objective of an SCM system is to ensure that goods and services are procured fairly, equitably, transparently, competitively and cost-effectively so that the goals of the national and/or provincial department are achieved. Therefore, performance management involves monitoring processes retrospectively in order to determine whether the objectives and goals have been achieved (Van der Waldt 2007:205; Ambe \& Badenhorst-Weiss 2011:14; MFMA [circular 22] 2006:50).

\section{Research design}

This research is descriptive and exploratory; important aspects of this article are based on existing research and primary sources that were explored in order to identify the possible suppler-relationship problems. A qualitative approach was adopted and based on a case study. Cooper and Schindler (2006:716) found that 'non-quantitative data collection is used to increase understanding of the topic'. The case study was conducted in KwaZulu-Natal. Primary data were gathered through face-to-face interviews with 15 participants at eight public sector institutions. The participants were selected using purposive sampling. Secondary data were gathered by means of a literature review.

The aim of using purposive sampling was to interview respondents in strategic positions who were able to clarify information and identify the possible supplier-relationship problems that are facing the public sector. In Table 1, the list of institutions contacted and the number of respondents
TABLE 1: List of public institutions.

\begin{tabular}{llc}
\hline $\begin{array}{l}\text { Case study } \\
\text { number }\end{array}$ & Public entity where the study was conducted & $\begin{array}{c}\text { Number of persons } \\
\text { interviewed }\end{array}$ \\
\hline 1 & Eskom & 1 \\
2 & KwaZulu-Natal Provincial Treasury & 2 \\
3 & University of Zululand & 1 \\
4 & Department of Economic Development and Tourism & 4 \\
5 & Msunduzi Municipality & 3 \\
6 & Department of Justice & 1 \\
7 & KwaZulu-Natal Transport & 1 \\
8 & South African State Information Technology & 2 \\
\hline Total & & 15 \\
\hline
\end{tabular}

interviewed is provided. Each interview was transcribed in report format, after which the findings of each particpant were reviewed, compared and combined. In some instances the transcripts were checked for accuracy and correctness by comparing them to digital recordings. The main limitation of this article is that only eight public institutions were included in the informal discussions. Therefore, the findings cannot be generalised. It is hoped that the findings of this article will pave the way for further research as the proposed five-stage framework is of an exploratory nature.

\section{Discussion of the results}

The result showed that public-sector institutions in KwaZuluNatal are experiencing supplier relationship issues that have a negative impact on the procurement process. These issues include the database, lack of experience, threats and bribery, maintaining integrity and delivery of goods and services. The challenges are discussed below.

\section{Database}

Public procurement is one of the yardsticks that accelerate small enterprise development. In order to comply with treasury regulations 16A (KwaZulu-Natal Provincial Treasury 2010), the National Treasury developed a supplier database to be used by public procurement officials. The purpose of this database is to give all prospective suppliers an equal opportunity to submit quotations to the relevant department and to enhance transparency and equality. The database contributes to better administration and compliance with the Public Finance Management Act. Preference is given to registered suppliers. Suppliers who are not yet registered are excluded from quoting for the supply of goods and services. All suppliers are invited to register as a preferred supplier on the National Treasury database.

In order to qualify for registration on the database prospective suppliers must have a valid tax-clearance certificate, a Cipro (Companies and intellectual property registration office) certificate and a certified identity document of a contact person. These documents must be submitted together with the application form and proof of banking details.

In accordance with the PFMA, Treasury Regulation 16A 9.1(c) (KwaZulu-Natal Provincial Treasury 2010) public entities may have their own database. Accounting officers or authorities are to: 
... check the National Treasury's database prior to awarding any contract to ensure that no recommended bidders, nor any of its directors, are listed as companies or persons prohibited from doing business with the public sector (KwaZulu-Natal Provincial Treasury 2010).

It is for this reason that the National Treasury manages a database known as the 'List of Restricted Suppliers' (KwaZulu-Natal Provincial Treasury 2010). It was confirmed that all participants included in this study routinely check the database prior to sending out quotations and tenders. This is to make sure that none of the names of the suppliers are found on the database to be persons prohibited from doing business with the public sector.

\section{Experience}

It was found that some suppliers lack experience, which compromises the quality of their goods or services and increases the cost of doing business. In general, suppliers who lack experience are encouraged to submit bids for quotations with a low rand value and a narrow scope of work. A supplier's experience is vital, particularly in construction projects. As much as public procurement wants all suppliers to benefit equally, there is no room for inexperience and some form of assurance that the contractor will be able to deliver is therefore required.

Some of the restrictive factors of certain suppliers are the lack of access to finance, low literacy levels, and inadequate management and organisational skills. In these instances, measures for developing these suppliers need to be considered.

\section{Threats and bribes}

It was found that some suppliers are politically connected; there have been instances where suppliers have threatened procurement officials when a contract is not awarded to them. Some suppliers are even on 'friendly terms' with the officials responsible for awarding the contract, making them more likely to acquire the contract. This results in nepotism and preferential contracting.

\section{Integrity}

A major challenge that was identified in this study is that some suppliers in the database falsely present the services they render. For example, a supplier will indicate that it renders a particular service and when awarded the order, it fails to deliver, resulting in the order being awarded to the next lowest-priced supplier, which is a waste of time and resources.

It was also found that some suppliers are awarded contracts more frequently than others because they have the advantage of financial resources that were acquired from previous contracts. Because these suppliers have the required resources for rendering the service, they have an advantage over other suppliers who do not have such financial resources available. This is in direct conflict with the policy that aims to uplift suppliers and not enrich them.

\section{Delivery}

One of the goals of the supply-chain framework is to empower affirmative suppliers and enhance Broad Based Black Economic Empowerment. In some instances, a tender is awarded to an intermediary supplier who qualifies for preferential points. This supplier then procures goods from a manufacturer. The problem that sometimes arises is that the intermediary supplier does not have the resources to pay the manufacturer and then asks the customer to intervene and pay the manufacturer. This results in the goods not being delivered on time. It was also found at times that wrong orders are received from suppliers. This is usually as a direct result of the order being placed late and pressure being exerted on the supplier to deliver as quickly as possible.

The discussion of the results reveals that there are supplierrelationship challenges in supply-chain practices in KwaZuluNatal. This hinders the establishment and maintenance of supplier relationships. Relationships with suppliers are of a transactional nature (arms length). The public sector has a social responsibility and is required to use all suppliers on the supplier database for everyone to benefit equally. In order to achieve this, suppliers on the database are rotated and multiple suppliers are used. This makes it impossible to establish supplier relationships and does not take the performance of the supplier into consideration. Hence, there is a need for the development of an SRM framework for the South African public sector.

\section{Supplier relationship management framework for the South African public sector}

In South Africa, central requirements of public procurement policy are transparency and a high standard of ethics, with the emphasis on treating all suppliers equally. Developing relationships with specific suppliers (as is often the case in private-sector procurement) is not only frowned upon, but is often forbidden outside a contractual relationship (Public Service Commission 2008:45). This is not only the case in South Africa, but also in other countries such as Australia.

The New South Wales (NSW) independent commission against corruption (ICAC), in reporting on corruption in NSW, made the following comment:

The current state of relationships between public officials and suppliers appears to be unsatisfactory to many parties. Concerns about probity appear to have constrained engagement between public officials and suppliers (ICAC 2011:27).

There is a view that merely the opportunity for unethical practices hampers the relationship between the government, the buyer and the supplier. In the same ICAC report, a supplier interviewed stated:

I think it's important to prevent corruption, but sometimes feel that it has become so rigid that any benefit that a supplier-client relationship has, may be lost. There are benefits in supplier relationships, not just problems (ICAC 2011:27). 
This is supported by the fact that there is seldom a link to unethical behaviour in the literature on SRM in the private sector. The fact that unethical issues occur from time to time does not stop procurement professionals and organisations from harnessing the benefits. Therefore, the possibility of unethical behaviour in dealing with suppliers prevents public procurement officials from implementing the benefits of SRM.

There is no reason why SRM cannot be married to the principles of public procurement. What it requires is an adaptation of SRM for the public sector. Even the United Nations, in the UN procurement practitioner's handbook (United Nations 2006:2-11), discusses the need to reduce risk and cost in strategic procurement, through the 'management of supplier relationships'.

Figure 2 presents a proposed five-stage framework that can be followed by public procurement officials in implementing SRM. This framework was based on the significant public sector experience of one of the authors. There is no reason why this process could not be followed by private sector procurement professionals, but they do not face the same level of scrutiny, or the requirement to keep their relationships with suppliers in close check, as their counterparts in the public sector. Therefore the following five-part process is specifically designed to assist the public sector procurement professional in implementing SRM.

Brief explanation of the five stages of this framework follows.

\section{Stage 1: Developing clear guidelines for procurement officials}

There must be clear guidelines set for public procurement officials as to what is considered acceptable and unacceptable behaviour in relation to communication with suppliers. Most public entities concentrate on information and training surrounding this, but as has been discussed previously, the possibility of corruption scares many public procurement officials off from approaching suppliers at all. Even the supply-chain guide for accounting officers (National Treasury 2004:20) considers that communication between public officials and suppliers is useful and necessary and that it could occur within clear parameters. There is a need to be fair and to provide the same information to all potential

\begin{tabular}{|l|l|}
\hline 1. & - Developing clear guidelines for procurement officials. \\
\hline 2. & - Developing clear guidelines for suppliers. \\
\hline 3. & - Highlighting information in bidding documents. \\
\hline 4. & - Documenting communications with suppliers. \\
\hline 5. & - Maintaining a relationship focused on the contract. \\
\hline
\end{tabular}

Source: Researchers' own construction

FIGURE 2: Five-stage framework. suppliers. This is certainly true for formal communications as no single supplier can receive an advantage over other suppliers. All formal approaches are documented so that an audit trail remains. However, it is with informal communications where potential problems occur, as they are not usually documented. Therefore, public procurement officials may need to retain a diary, journal or file notes to record communications with suppliers.

\section{Stage 2: Developing clear guidelines for suppliers}

Public procurement officials should provide clear guidelines to suppliers in relation to their dealings with suppliers. There needs to be a distinct difference between the relationship prior to a contract and the relationship after signing the contract. Therefore, in the public sector, providing information to suppliers regarding the communication process and any subsequent relationship issues will enhance understanding for both parties.

\section{Stage 3: Highlighting information in bidding documents}

The bidding process requires government procurement officials to make contact with suppliers about aspects related to the potential contract. The bidding documents should clarify that contact may take place and the circumstances under which it may take place. If suppliers are fully informed of the government procurement process they are less likely to be concerned about situations that may occur in relation to other suppliers.

\section{Stage 4: Documenting communications with suppliers}

Any communications, particularly those prior to awarding the contract, need to be documented. Therefore, public procurement officials should be encouraged to ensure that all communications with suppliers are recorded for future audit purposes or other investigations.

\section{Stage 5: Maintaining a relationship focused on the contract}

Once the contract has been awarded, there is an obvious need to maintain contact and communication with the incumbent supplier. In a private-sector environment, as stated earlier in the paper, the process of managing the relationship is crucial in order to ensure the continued performance of the contract and the development of long-term mutual benefits for both organisations. This relationship may develop in both a formal and informal setting; there is no indication that it will be unethical. There is no difference in the requirement to manage the contract and develop a relationship in public-sector procurement. However, for reasons of public transparency and scrutiny, the relationship needs to be on a formal basis only and focused on the contract at hand. A friendly and cordial relationship does not mean an unethical relationship, however, the public procurement official needs to take a more formal approach to the relationship. 


\section{Conclusion}

Purpose of this article was to explore supplier relationships in the public procurement sector in KwaZulu-Natal. The public sector in KwaZulu-Natal has an important role to play in South Africa and is important in the overall economy of the country. This article provides insight into the processes followed by the public sector to procure goods and services.

The opportunities and challenges of globalisation and the constant demand for speed and cost containment make it necessary for businesses in the private sector to establish relationships with their suppliers. Although the private and public sector share the same procurement objectives of procuring goods and services effectively and efficiently, procurement in the public sector is a regulated, open process defined and controlled by numerous laws, rules and regulations, policies and procedures. Purchases by the public sector represent a substantial amount of public resources spend and it is therefore policy that procurement in South Africa be used as a tool to achieve socioeconomic upliftment. As such, SCM in all government bodies must work within a legislative framework based on the norms and standards that create uniformity.

Developing and managing supplier relationships are crucial to the procurement of goods and services for any organisation, in this regard public-sector procurement is no different. There is no need for government procurement officials to fear the relationship; there is simply a need to manage it differently from the private sector. The need for transparency and a higher standard of ethical behaviour on the part of public procurement officials means that the way SRM is dealt with needs to be adapted.

The discussion reveals that supplier relationships in the public sector are of a transactional nature owing to the fact that the SCM policy restricts anyone in public-sector procurement from building relationships with their suppliers. In addition, the policy requires that suppliers on their database are rotated on the premise that the public sector has a social responsibility to use all suppliers listed on the database.

This article suggests that by implementing the five-stage framework, public procurement officials can reap the benefits of SRM whilst supporting the requirements of public-sector procurement. There is no doubt that goods and services satisfy the needs of the communities served by the public entities and also provide value for money. It is vital that public entities implement their development agenda successfully and fulfil the mandate assigned to them by the Constitution.

\section{Acknowledgements Competing interests}

The authors declare that they have no financial or personal relationship(s) that may have inappropriately influenced them in writing this article.

\section{Authors' contributions}

M.N. (University of KwaZulu-Natal) was the initiator of the article and contributed $50 \%$ of the article. M.A. (University of South Africa) checked the final article for accuracy and reliability of secondary and empirical data, and provided valuable input and contributed $20 \%$ of the article. R.K. (Supply Chain Management Education) was the author who was responsible for designing the five-stage framework and contributed $30 \%$ of the article.

\section{References}

Ambe, I.M. \& Badenhorst-Weiss, J.A., 2011, An examination of supply chain management practices in the South African public sector, Conference proceedings of the 20th International Purchasing and Supply Education and Research Association conference, Maastricht University, April 10-13, 2011, pp.2-18.

Bailey, P., Farmer, D., Jessop, D. \& Jones, D., 2005, Purchasing Principles and Management, 9 th edn., Prentice Hall, Harlow, England.

Beth, S., Burt, D.N., Copacino, W., Gopal, C., Lee, H.L., Lynch, R.P. \& Morris, S., 2006 Supply chain challenges: Building relationships, Harvard Business Review on Supply Chain Management, Harvard Business School Press, Boston, pp.65-86.

Burt, D.N., Dobler, D.W. \& Starling, S.L., 2003, World class supply management, 7th International edn., McGraw-Hill Irwin, Boston.

Burt, D.N., Petcavage, S. \& Pinkerton, R., 2010, Supply management, 8th edn., McGrawHill Irwin, Boston.

Cooper, D.R. \& Schindler, P.S., 2006, Business research methods, 9th edn., McGraw-Hill, Boston.

Dobler, D. \& Burt, D., 2000, Purchasing and Supply Management - Texts and Cases, 6 th edn., McGraw-Hill, Singapore.

Fawcett, S.E., Ellram, L.M. \& Ogden, J., 2007, Supply chain management: from vision to implementation, Pearson Prentice-Hall, Upper Saddle River, New Jersey.

Ganesan, S., Brown, S.P., Mariadoss B.J. \& Ho, H., 2010, 'Buffering and amplifying effects of relationship commitment in business-to-business relationships', Journal of Marketing Research 47, 361-373. http://dx.doi.org/10.1509/jmkr.47.2.361

Gullett, J., Do, L., Canuto-Carranco, M., Brister, M., Turner, S. \& Caldwell, C., 2010, 'The buyer-supplier relationship: An integrative model of ethics and trust', Journal of Business Ethics 90, 329-341. http://dx.doi.org/10.1007/s10551-010-0430-4

Hugo, W.M.J., Badenhorst-Weiss, J.A. \& van Biljon, E.H.B., 2006, Purchasing and Supply Management, 5th edn., Van Schaik, Pretoria.

Hugo, W.M.J. \& Badenhorst-Weiss, J.A., 2011, Purchasing and Supply Management, 6th edition, Van Schaik, Pretoria.

ICAC, 2011, New South Wales Independent Commission Against Corruption, Corruption Risks in NSW Government Procurement, ICAC, Sydney.

KwaZulu-Natal Provincial Treasury, 2010, 'Annual Report', viewed 02 October 2011, from: http://www.treasury.gov.za

Mangan, J., Lalwani, C., Butcher, T. \& Javadpour, R., 2012, Global logistics and supply chain management, John Wiley \& Sons, Croyden.

Municipal Finanacial Management Act (M) [circular 22], 2006, Municipal Supply Chain Management Policy, 25 August, Department of National Treasury, Republic of South Africa.

Moeti, K., Khalo, T., Mafunisa, S., Nsingo, S. \& Makonda, T., 2007, Public Finance Fundamentals, 1st edn., Juta Academic, South Africa.

Monczka, R.M., Handfield, R.B., Giunipero, L.C., Patterson, J.L. \& Waters, D., 2010, Purchasing and supply chain management, South-Western Cengage Learning, Hampshire, UK

National Treasury, 2004, Supply Chain Management: A guide for accounting officers/ authorities, Republic of South Africa, February 2004, viewed 05 May 2012, from http://mfma.treasury.gov.za

National Treasury, 2005, Supply Chain Management: A guide for accounting officers and municipal entities, Republic of South Africa, October 2005, viewed 11 July 2011, from http://mfma.treasury.gov.za

Pauw, J., Woods, G., Van der Linde, G., Fourie, D. \& Visser, C., 2002, Managing Public Money, 1st edn., Heinemann, South Africa.

Peterson, A.D.M., 2005, Supply Chain Management: Local Government Perspective, Deputy Head: SCM Policy and Support Services, eThekwini Municipality, viewed 11 July 2011, from http://www.ddp.org.za

Public Service Commission, 2008, Report on the management of gifts in the public sector, Public Service Commission, Custodian of Good Governance, viewed 05 May 2012, from http://www.info.gov.za

Republic of South Africa, 2000, Preferential Procurement Policy Framework Act (PPPFA) (Act 5 of 2000), Cape Town: Government Gazette, vol. 16, no. 20854.

Republic of South Africa, 2000, Public Finance Management Act (PFMA) (Act 1 of 1999), Cape Town: Government Gazette no. 33059, Cape Town: Government Gazette, vol. 463 , no. 25899. 
Republic of South Africa, 2001, Treasury Regulations for Departments, Constitutional Institutions and Public Entities, Public Finance Management Act (PFMA) Treasury
Regulation 16A 9.1(c). Republic of South Africa, 2004, Local Government: Municipal Finance Management Act (MFMA) (Act 56 of 2003).

Saunders, M., 1997, Strategic Purchasing \& Supply Chain Management, Prentice Hall, Essex.

Statutes of the Republic of South Africa, 1997, Consitutional Law, Constitution of the Republic of South Africa (Act 108 of 1996).

Stevenson, W.J., 2009, Operations management, 10th edn., International edn., McGraw Hill, Boston

Swink, M., Melnyk, S.A., Cooper, M.B. \& Hartley, J.L., 2011, Managing operations across the supply chain, McGraw-Hill, New York. PMCid:3240935
United Nations, 2006, UN Procurement Practitioner's Handbook, Interagency Procurement Working Group.

Van der Waldt, G., 2007, Municipal management: Serving the people, Juta \& Co. Ltd, Cape Town.

Van Weele, A.J., 2010, Purchasing and supply chain management: Analysis, strategy, planning and practice, 4th edn, Thomson Learning, Australia. PMid:20565481

Wisner, J.D., Tan, K.C. \& Leong, G.K., 2009, Principles of supply chain management: A balanced approach, South-Western Cengage Learning, Mason $\mathrm{OH}$.

Wu, M.Y. \& Weng, Y.C., 2010, 'A study of supplier selection factors for high-tech industries in the supply chain', Total Quality Management 21(4), 391-413. http://dx.doi. org/10.1080/14783361003606662 